\title{
Article \\ Mechanical Properties of Glass-Based Geopolymers Affected by Activator and Curing Conditions under Optimal Aging Conditions
}

\author{
Tai-An Chen (D)
}

Citation: Chen, T.-A. Mechanical Properties of Glass-Based

Geopolymers Affected by Activator and Curing Conditions under Optimal Aging Conditions. Crystals 2021, 11, 502. https://doi.org/ $10.3390 /$ cryst11050502

Academic Editors: Salman Siddique and Nima Farzadnia

Received: 9 April 2021

Accepted: 29 April 2021

Published: 2 May 2021

Publisher's Note: MDPI stays neutra with regard to jurisdictional claims in published maps and institutional affiliations.

Copyright: (C) 2021 by the author. Licensee MDPI, Basel, Switzerland. This article is an open access article distributed under the terms and conditions of the Creative Commons Attribution (CC BY) license (https:// creativecommons.org/licenses/by/ $4.0 /)$.
Department of Harbor and River Engineering, National Taiwan Ocean University, No. 2, Pei-Ning Rd., Zhongzheng Dist., Keelung City 202301, Taiwan; tachen@mail.ntou.edu.tw, Tel.: +886-2-2462-2192

\begin{abstract}
Inorganic polymeric materials react slowly at room temperature and therefore, usually require high-temperature curing. This study determined the correlation between temperature and duration in high-temperature curing. The results revealed optimal values for each alkali equivalent of an activator (weight ratio of $\mathrm{Na}_{2} \mathrm{O}$ /glass powder), curing temperature, and curing duration. Increasing the curing duration and curing temperature had positive effects when the alkali equivalent was lower than the optimal percentage. However, over-curing resulted in the visible cracking of the specimens. Furthermore, despite being initially high, the compressive strength of specimens gradually diminished after standing in air. To ensure the durability of glass-based geopolymers, the curing temperature and duration should not exceed $70{ }^{\circ} \mathrm{C}$, and 1 day, respectively.
\end{abstract}

Keywords: waste glass; inorganic binder; curing temperature; curing duration

\section{Introduction}

The relentless usage of natural resources to fuel economic growth has resulted in the problem of resource shortage [1]. Therefore, the reuse of waste products and the use of environmentally friendly materials have become growing international concerns [2]. Portland cement is the most commonly used inorganic cementing material in civil engineering; however, its production involves one grinding process as well as two burning processes at high temperature of $1300 \sim 1400{ }^{\circ} \mathrm{C}$, generating 1 ton of carbon dioxide per ton of cement [3]. Global cement production accounts for $5-7 \%$ of global annual greenhouse gas emissions $[3,4]$, and the amount of greenhouse gases generated in cement production is increasing by $5 \%$ each year [3]. Thus, developing a low-cost, low polluting inorganic cementing material with low energy requirements as a replacement for Portland cement is crucial for environment protection. Alkali-activated binders are possible replacements for Portland cement.

Alkali-activated binder materials are essentially cementing materials consisting of aluminosilicates, alkaline solution, and alkali silicate solution. Aluminosilicates, which dissolve in strong alkaline solutions to release sufficient quantities of Si and Al, can supply sufficient amounts of silicate oligomers to enhance the polymerization of alkali-activated binders [5,6], for example, by increasing the strength and density of binder microstructure. Alkali-activated binder materials are environmentally friendly. Moreover, they require a considerably lower calcination temperature than Portland cement $\left(1400{ }^{\circ} \mathrm{C}\right)$, produce 20-50\% less $\mathrm{CO}_{2}$ and consume less energy [7]. In addition, their weathering resistance, acid erosion properties, and fire insulation properties are superior. Currently, alkali-activated binder materials are used in applications such as fire insulation, waste solidification, and structural materials production [8-11].

Alkali-activated cementitious materials are produced using various raw materials, such as metakaolin [9,12], ground-granulated blast-furnace slag (GGBFs) [13], fly ash [14], silica fume [15], bottom ash [16], graphene oxide [17], construction and demolition waste [18], 
eggshell powder [19], and calcined reservoir sludge [20]. These materials are mixed with an activator that is usually composed of alkali metal hydroxide and sodium silicate. In the alkali-activation reaction of inorganic polymers, the dissolution of the ions of aluminosilicate minerals is mainly caused by alkali metal hydroxide. The subsequent polycondensation of some silicate precursors is partially caused by sodium silicate. Compared with Portland cement, inorganic binders have a substantially higher compressive strength due to their mixture with activators of sodium hydroxide and sodium silicate.

Alkali-activated inorganic binders are categorized into two types according to their microstructures: alkali-activated slag (AAS) and geopolymer. AAS has a microstructure with a low $\mathrm{Ca} / \mathrm{Si}$ ratio and contains C-S-H gel [21]. Geopolymer, also known as Class-F fly ash, has a colloidal microstructure containing tetrahedron $\mathrm{SiO}_{4}$ and $\mathrm{AlO}_{4}^{-}[22,23]$.

If they are to be competitive with traditional types of cement, binders composed of waste products must have lower manufacturing costs. This study used 100\% waste glass to create an alkali-activated binder. The composition was optimized to reduce the cost of activator use and improve the material properties. Habert et al. suggested using industrial waste with a suitable molar ratio to reduce the amount of sodium silicate required in activators because the productions of sodium silicate exerts more severe environment impacts than does that of Portland cement [24]. Waste glass has the aforementioned characteristics, and studies have found that glass is a suitable geopolymer. Luhar et al. reviewed various studies on the effects of glass geopolymers on durability, thermal properties, and microstructural properties [25]. Waste glass is also recycled in ceramics [26] and used as a material in cement firing [27], foam glass firing [28], concrete [29], and asphalt [30]. Christiansen examined the influence of different types of glass and alkali activators on the properties of geopolymers [31]. Chen et al. [32] proposed an aging process to produce glass-based geopolymers with mechanical properties equivalent to those of geopolymers not containing silicate. Another study indicated that changing the curing conditions can enhance the mechanical properties of glass-based geopolymers [33]. The current study, which is based on the study by Chen et al. [32], used waste glass as an activator to replace sodium silicate, which is expensive and environmentally unfriendly. The curing conditions were adjusted under optimal aging conditions to determine whether the adjustment of curing temperature and duration resulted in variations in the performance of the glass-based geopolymer, the compressive strength of which was correlated with the durability, bending strength, and shear strength of concrete.

\section{Materials and Methods}

\subsection{Raw Materials}

After the selection and transport of waste glass containers from a recycling plant to a laboratory, various steps must be performed before they could be used as raw material for geopolymer fabrication. First, the glass bottles were cleaned and dried in air. Next, the bottles were crushed to a particle size of less than $300 \mu \mathrm{m}$ and then ground into powder by using a pan mill. The physical and chemical properties of the glass powder are presented in Table 1. The X-ray diffraction (XRD) patterns of the glass powder (Figure 1), which were obtained at a scanning rate of $2 \theta / \mathrm{min}$ and over a scanning range of $10^{\circ}-80^{\circ}$, revealed highly amorphous characteristics. The physical properties, chemical properties, and XRD patterns of the glass powder indicate that it had a high content of reactive silica, one of the most crucial substances to geopolymer formation. In short, glass powder was successfully used to replace sodium silicate in geopolymer preparation.

Table 1. Physical and chemical properties of the glass powder produced from waste glass in this study.

\begin{tabular}{cccccccccc}
\hline $\mathrm{SiO}_{2}$ & $\mathrm{Al}_{2} \mathrm{O}_{3}$ & $\mathrm{Fe}_{2} \mathbf{O}_{3}$ & $\mathbf{C a O}$ & $\mathbf{M g O}$ & $\mathbf{N a}_{\mathbf{2}} \mathbf{O}$ & $\mathbf{K}_{\mathbf{2}} \mathbf{O}$ & $\mathbf{G}_{\mathbf{s}}$ & Absorption & Specific Surface Area \\
\hline $72.5 \%$ & $2 \%$ & $0.06 \%$ & $10.5 \%$ & $1 \%$ & $13 \%$ & $0.5 \%$ & 2.55 & $0.2 \%$ & $4303 \mathrm{~cm}^{2} / \mathrm{g}$ \\
\hline
\end{tabular}




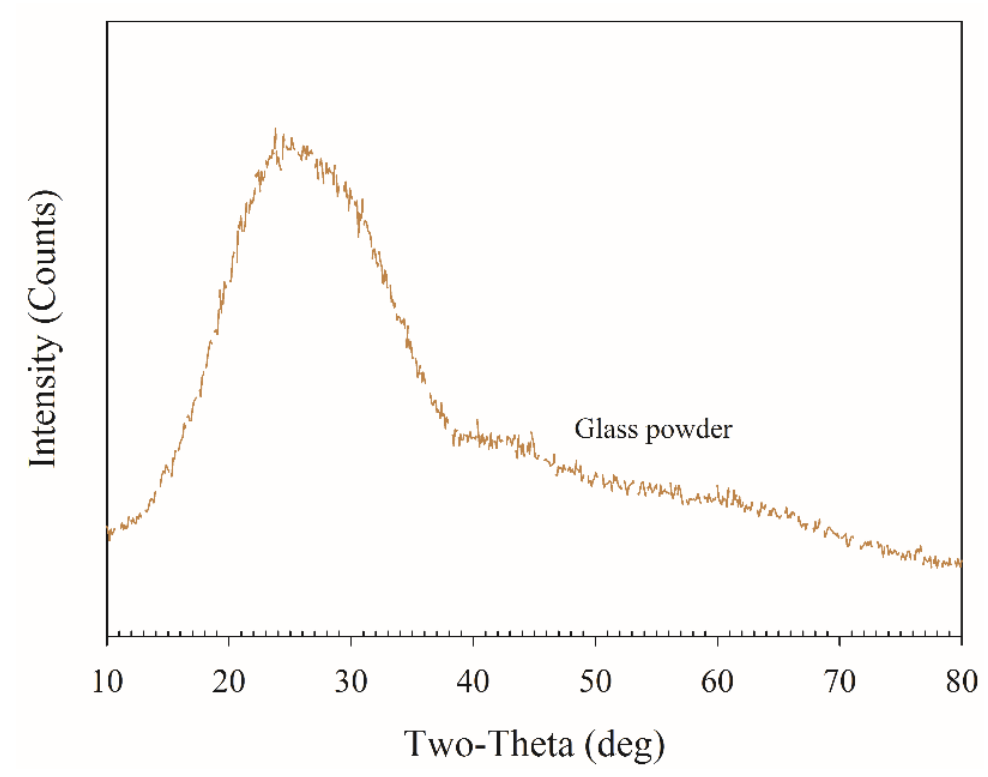

Figure 1. X-ray diffraction patterns of the glass powder.

\subsection{Activator}

Two parameters were used to examine the effects of the activator: the alkali-equivalent content $(\mathrm{AE} \%)$ and the water/binder $(\mathrm{W} / \mathrm{B})$ ratio. The alkali-equivalent content is defined as the ratio of the weight fraction of $\mathrm{Na}_{2} \mathrm{O}$ to glass powders. The $\mathrm{W} / \mathrm{B}$ ratio is the ratio of the weight of water to the summed weights of glass powders. Sodium hydroxide $(99 \%$; ECHO Chemical Co., Ltd.) was used as the activator, and the W/B ratio was fixed as 0.3 for all the glass-based geopolymer specimens. The mixture proportions of the specimens with varying $\mathrm{AE} \%=1-6 \%$ are listed in Table 2 .

Table 2. Mixture proportions of the glass-based geopolymer specimens with varying $\mathrm{AE} \%=1-6 \%$.

\begin{tabular}{ccccc}
\hline W/B & AE\% & Sodium Hydroxide $(\mathrm{g})$ & Water $(\mathrm{g})$ & Glass Powder $(\mathrm{g})$ \\
\hline & $1 \%$ & 12.91 & 303.87 & 1000 \\
& $2 \%$ & 25.82 & 307.75 & 1000 \\
0.3 & $3 \%$ & 38.73 & 311.62 & 1000 \\
& $4 \%$ & 61.64 & 315.49 & 1000 \\
& $5 \%$ & 77.55 & 319.37 & 1000 \\
& $6 \%$ & 323.24 & 1000 \\
\hline
\end{tabular}

\subsection{Aging Process}

First, sodium hydroxide was mixed thoroughly with water; then, the alkali solution was cooled to room temperature. Next, a bath tank was heated to the preset aging temperature by using a temperature-controlled heating device, and the glass powder and alkali-activator mixture were poured into a sequencing batch reactor, after which they were combined by using a direct current (DC) mixer at $500 \mathrm{rpm}$ for $30 \mathrm{~s}$ at room temperature. The mixture was then covered with plastic wrap and placed in a water bath to maintain its temperature. Mixing was continued at $500 \mathrm{rpm}$ with the DC mixer until the preset time, after which the mixture was poured into $3 \mathrm{~cm} \times 3 \mathrm{~cm} \times 3 \mathrm{~cm}$ three-gang cube molds in two layers. The mixtures were tamped at a frequency of $60 \mathrm{~Hz}$ by using a vibration table (Italy CONTROLS) to eliminate the bubbles within the specimens. The following aging times were adopted for $\mathrm{AE} \%$ of $1-6 \%$ below the aging temperature of $70{ }^{\circ} \mathrm{C}: 105,55,40,35$, and $25 \mathrm{~min}$ [32]. 


\subsection{Curing Process}

To prevent moisture loss, the specimens were wrapped with plastic film and then placed into an oven, with the molds, for curing over a preset duration. The specimens were removed from the oven and demolded when they had cooled to room temperature and then allowed to stand at room temperature for 4 days. The curing temperatures for each glass slurry and $\mathrm{AE} \%$ were $60^{\circ} \mathrm{C}, 70^{\circ} \mathrm{C}, 80^{\circ} \mathrm{C}, 90^{\circ} \mathrm{C}$, and $100{ }^{\circ} \mathrm{C}$. The curing durations were increased by $8 \mathrm{~h}$ until 4 days had passed. For instance, a curing duration of $8 \mathrm{~h}$ indicates that the specimens were in the oven for $8 \mathrm{~h}$, demolded, and then maintained at room temperature for $88 \mathrm{~h}$. The curing was completed over 4 days, after which the compressive strength of the specimens was measured using a Shimadzu UHC-100A universal tester with a constant loading speed of $300 \mathrm{KPa} / \mathrm{s}$ for stress control.

\subsection{Specimen Strength Development}

To determine the effect of curing temperature on the compressive strength of the specimens, the compressive strength was measured at $\mathrm{AE} \%$ of $3 \%$ and $6 \%$; a curing duration of $24 \mathrm{~h}$; standing times of $0,7,14,21$, and 28 days; and curing temperatures between $60^{\circ} \mathrm{C}$ and $100{ }^{\circ} \mathrm{C}$. Specifically, the compressive strength was measured at a curing temperature of $70{ }^{\circ} \mathrm{C}$; curing durations of $8,16,24,48$, and $96 \mathrm{~h}$; and a standing time of 0 days. It was also measured after the specimens had cooled to room temperature (in approximately $1 \mathrm{~h}$ ). For the remaining curing durations, we measured compressive strength after letting the specimens stand in the air for the corresponding period.

\section{Results and Discussion}

\subsection{Effects of the $A E \%$ on the Curing Process}

Table 3 presents the curing conditions corresponding to the optimal compressive strength for each $\mathrm{AE} \%$. At the same curing temperature, a higher $\mathrm{AE} \%$ corresponded to a shorter optimal curing duration. For instance, for a curing temperature of $80{ }^{\circ} \mathrm{C}$, the optimal curing duration was $64 \mathrm{~h}$ when the $\mathrm{AE} \%$ was $1 \%$. This duration shortened to 48 and $40 \mathrm{~h}$ when the $\mathrm{AE} \%$ was $3 \%$ and $6 \%$, respectively. Regardless of the curing conditions, all the final compressive strengths, except those at a curing temperature of $60{ }^{\circ} \mathrm{C}$ and $\mathrm{AE} \%$ of $1 \%$ and $2 \%$, were controlled by the $\mathrm{AE} \%$. For a curing temperature of $60^{\circ} \mathrm{C}$ and $\mathrm{AE} \%$ of $1 \%$ and $2 \%, 4$ days was insufficient for the specimens to reach their ultimate compressive strength (indicated by $<>$ in Table 3). The researcher speculates that by extending the curing duration, the approximate ultimate compressive strength can be reached under the aforementioned conditions. When the curing duration is shorter than the optimal curing duration, an increase in the curing temperature or curing duration causes $\mathrm{OH}^{-}$to bond with additional $\mathrm{Si}$ and $\mathrm{Al}$, which are required for geopolymer formation. However, if the curing duration exceeds the optimal curing duration, water molecules and $\mathrm{OH}^{-}$ ions may diffuse to the surface of undissolved glass particles and corrode them [34]. The higher the $\mathrm{AE} \%$, the more severe this corrosion. An increase in the curing duration causes an increasing number of $\mathrm{OH}^{-}$ions to corrode polymerized glass-based geopolymers, reducing its compressive strength. Thus, polymers with lower $\mathrm{AE} \%$ require higher curing temperatures or longer curing durations. This result is similar to the conclusion presented by Chen [33].

\subsection{Effects of the Curing Temperature on the Compressive Strength}

Figures $2-4$ indicate that before the optimal AE\% (3\%) was reached, the compressive strength of the glass-based geopolymer increased with the curing temperature $\left(60{ }^{\circ} \mathrm{C}\right.$, $70{ }^{\circ} \mathrm{C}, 80^{\circ} \mathrm{C}, 90^{\circ} \mathrm{C}$, and $100{ }^{\circ} \mathrm{C}$ ) at a fixed curing duration of $24 \mathrm{~h}$. When $\mathrm{AE} \%=1 \%$, the compressive strength increases from $25.87 \mathrm{MPa}$ to $65.31 \mathrm{MPa}$; when $\mathrm{AE} \%=2 \%$, the compressive strength increases from $44.56 \mathrm{MPa}$ to $82.31 \mathrm{MPa}$, and when $\mathrm{AE} \%=3 \%$, the compressive strength increases from $85.85 \mathrm{MPa}$ to $96.21 \mathrm{MPa}$ under increases in the curing temperature from $60{ }^{\circ} \mathrm{C}$ to $100{ }^{\circ} \mathrm{C}$. When the curing duration was extended to $48 \mathrm{~h}$, an optimal compressive strength of $69.96 \mathrm{MPa}$ was achieved at an $\mathrm{AE} \%$ of $1 \%$ and a curing 
temperature of $90{ }^{\circ} \mathrm{C}$. For the same curing duration, optimal compressive strengths of 101.89 and $129.97 \mathrm{MPa}$ were achieved at $\mathrm{AE} \%$ of $2 \%$ and $3 \%$, respectively, under a curing temperature of $80^{\circ} \mathrm{C}$.

Table 3. Ultimate compressive strengths of the specimens under various curing temperatures when $\mathrm{AE} \%=1-6 \%$.

\begin{tabular}{|c|c|c|c|c|c|c|}
\hline \multirow[b]{2}{*}{$\begin{array}{c}\text { Curing } \\
\text { Temperature } \\
\left({ }^{\circ} \mathrm{C}\right)\end{array}$} & \multicolumn{2}{|c|}{$\mathrm{AE} \%=1 \%$} & \multicolumn{2}{|c|}{$\mathrm{AE} \%=2 \%$} & \multicolumn{2}{|c|}{$\mathrm{AE} \%=3 \%$} \\
\hline & $\begin{array}{c}\text { Curing } \\
\text { Duration } \\
\text { (h) }\end{array}$ & $\begin{array}{l}\text { Compressive } \\
\text { Strength } \\
\text { (MPa) }\end{array}$ & $\begin{array}{c}\text { Curing } \\
\text { Duration } \\
\text { (h) }\end{array}$ & $\begin{array}{l}\text { Compressive } \\
\text { Strength } \\
\text { (MPa) }\end{array}$ & $\begin{array}{l}\text { Curing } \\
\text { Duration } \\
\text { (h) }\end{array}$ & $\begin{array}{c}\text { Compressive } \\
\text { Strength } \\
\text { (MPa) }\end{array}$ \\
\hline 60 & 96 & $<55.24>$ & 96 & $<76.26>$ & 96 & 129.65 \\
\hline 70 & 88 & 71.97 & 88 & 106.72 & 80 & 136.77 \\
\hline 80 & 64 & 69.53 & 48 & 101.89 & 48 & 129.97 \\
\hline 90 & 48 & 69.96 & 32 & 85.89 & 32 & 126.83 \\
\hline 100 & 24 & 65.31 & 24 & 82.31 & 24 & 96.21 \\
\hline \multicolumn{2}{|c|}{ Ultimate compressive strength } & 69.19 & & 94.20 & & 123.89 \\
\hline & \multicolumn{2}{|c|}{$\mathrm{AE} \%=4 \%$} & \multicolumn{2}{|c|}{$\mathrm{AE} \%=5 \%$} & \multicolumn{2}{|c|}{$\mathrm{AE} \%=6 \%$} \\
\hline $\begin{array}{c}\text { Curing } \\
\text { Temperature } \\
\left({ }^{\circ} \mathrm{C}\right)\end{array}$ & $\begin{array}{l}\text { Curing } \\
\text { Duration } \\
\text { (h) }\end{array}$ & $\begin{array}{c}\text { Compressive } \\
\text { Strength } \\
\text { (MPa) }\end{array}$ & $\begin{array}{l}\text { Curing } \\
\text { Duration } \\
\text { (h) }\end{array}$ & $\begin{array}{c}\text { Compressive } \\
\text { Strength } \\
\text { (MPa) }\end{array}$ & $\begin{array}{l}\text { Curing } \\
\text { Duration } \\
\text { (h) }\end{array}$ & $\begin{array}{c}\text { Compressive } \\
\text { Strength } \\
\text { (MPa) }\end{array}$ \\
\hline 60 & 96 & 122.62 & 88 & 119.25 & 88 & 108.17 \\
\hline 70 & 64 & 119.65 & 64 & 107.96 & 56 & 103.60 \\
\hline 80 & 48 & 105.34 & 48 & 114.84 & 40 & 115.91 \\
\hline 90 & 32 & 103.05 & 32 & 100.72 & 24 & 109.37 \\
\hline 100 & 16 & 111.24 & 16 & 97.01 & 8 & 96.86 \\
\hline \multicolumn{2}{|c|}{ Ultimate compressive strength } & 112.38 & & 107.96 & & 106.78 \\
\hline
\end{tabular}

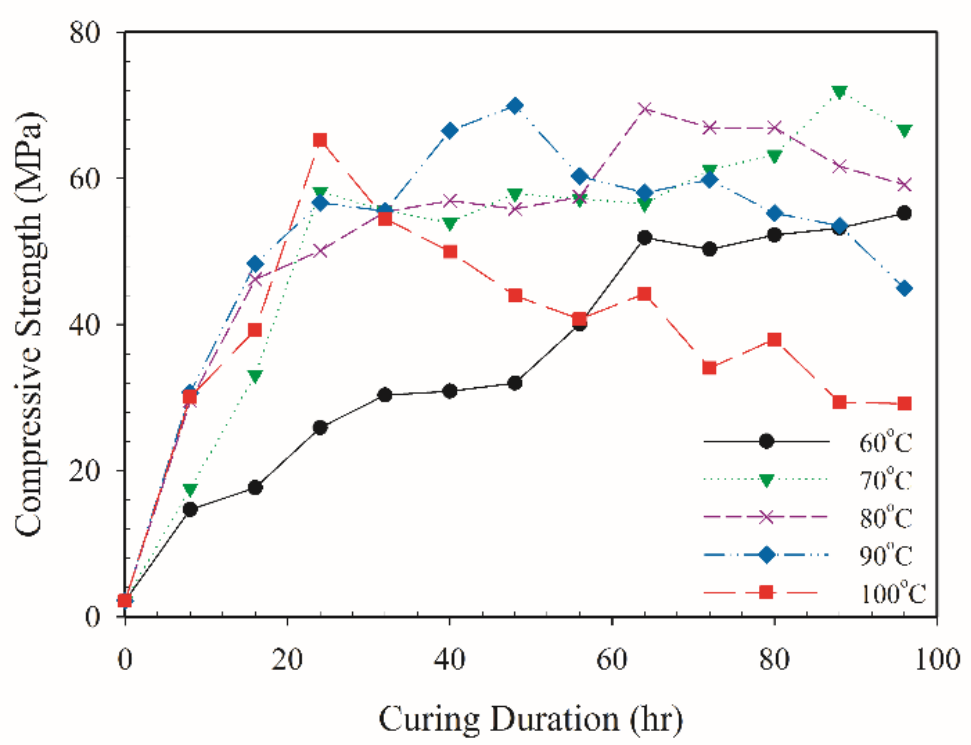

Figure 2. Variations with curing duration in the 4-day compressive strength of geopolymer specimens at various curing temperatures when $\mathrm{AE} \%=1 \%$. 


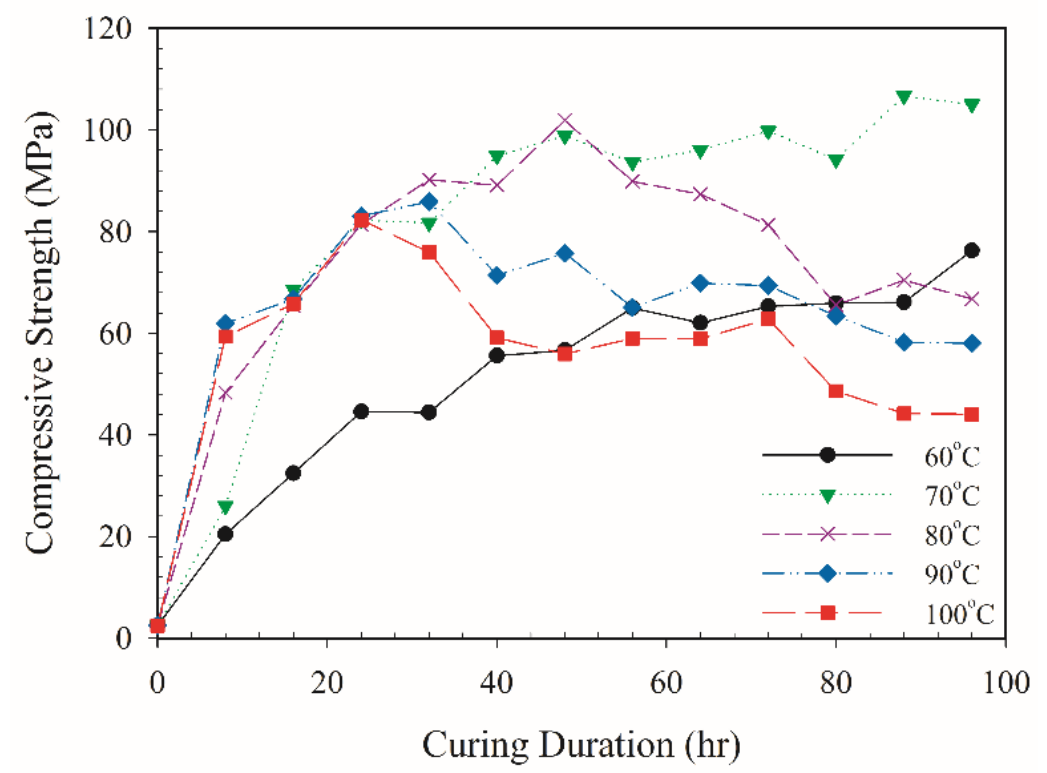

Figure 3. Variations with curing duration in the 4-day compressive strength of geopolymer specimens at various curing temperatures when $\mathrm{AE} \%=2 \%$.

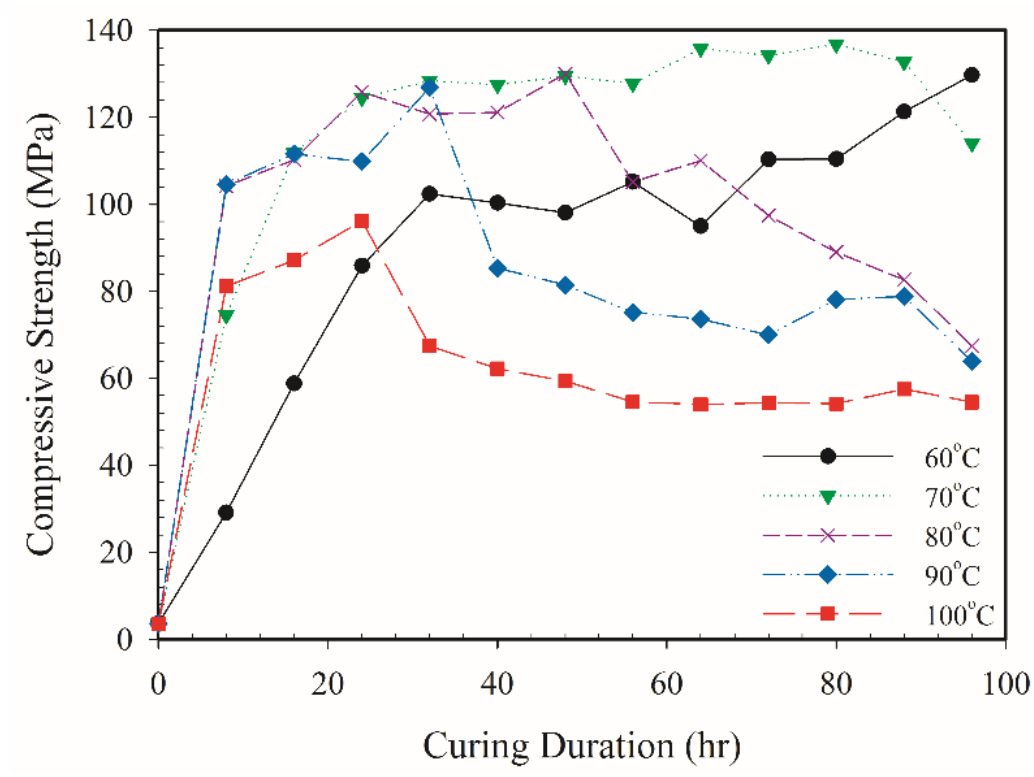

Figure 4. Variations with curing duration in the 4-day compressive strength of geopolymer specimens at various curing temperatures when $\mathrm{AE} \%=3 \%$.

Figures 5-7 present the variations with curing duration in the compressive strength of the geopolymer specimens at various curing temperatures when the optimal $\mathrm{AE} \%$ of $3 \%$ was exceeded. For a curing duration of $24 \mathrm{~h}$, the compressive strengths of the specimens with $\mathrm{AE} \%$ of $4 \%, 5 \%$, and $6 \%$ increased from 73.16 to $94.09 \mathrm{MPa}, 77.19$ to $83.28 \mathrm{MPa}$, and 72.84 to $109.37 \mathrm{MPa}$, respectively, under increases in the curing temperature from $60{ }^{\circ} \mathrm{C}$ to $90{ }^{\circ} \mathrm{C}$. However, when the curing temperature increased to $100{ }^{\circ} \mathrm{C}$, the compressive strengths of the specimens with $\mathrm{AE} \%$ of $4 \%, 5 \%$, and $6 \%$ decreased to $88.64,71.13$, and $71.98 \mathrm{MPa}$, respectively. When the curing duration was increased to $48 \mathrm{~h}$, the compressive strengths of the specimens with $\mathrm{AE} \%$ of $5 \%$ and $6 \%$ increased with the curing temperature between $60{ }^{\circ} \mathrm{C}$ and $80^{\circ} \mathrm{C}$ but decreased with the curing temperature between $80^{\circ} \mathrm{C}$ and $100{ }^{\circ} \mathrm{C}$. For example, when $\mathrm{AE} \%=5 \%$, the compressive strength increased from 98.80 to 114.84 MPa between $60^{\circ} \mathrm{C}$ and $80^{\circ} \mathrm{C}$ and then decreased to $55.02 \mathrm{MPa}$ at $100^{\circ} \mathrm{C}$. By contrast, 
when $\mathrm{AE} \%=6 \%$, the compressive strength remained relatively constant between $60{ }^{\circ} \mathrm{C}$ and $80^{\circ} \mathrm{C}$, with com-pressive strengths of $95.82,92.59$, and $94.03 \mathrm{MPa}$ at curing temperatures of $60{ }^{\circ} \mathrm{C}, 70{ }^{\circ} \mathrm{C}$, and $80^{\circ} \mathrm{C}$, respectively. When the curing temperature increased to $100{ }^{\circ} \mathrm{C}$, the compressive strength decreased to $49.27 \mathrm{MPa}$.

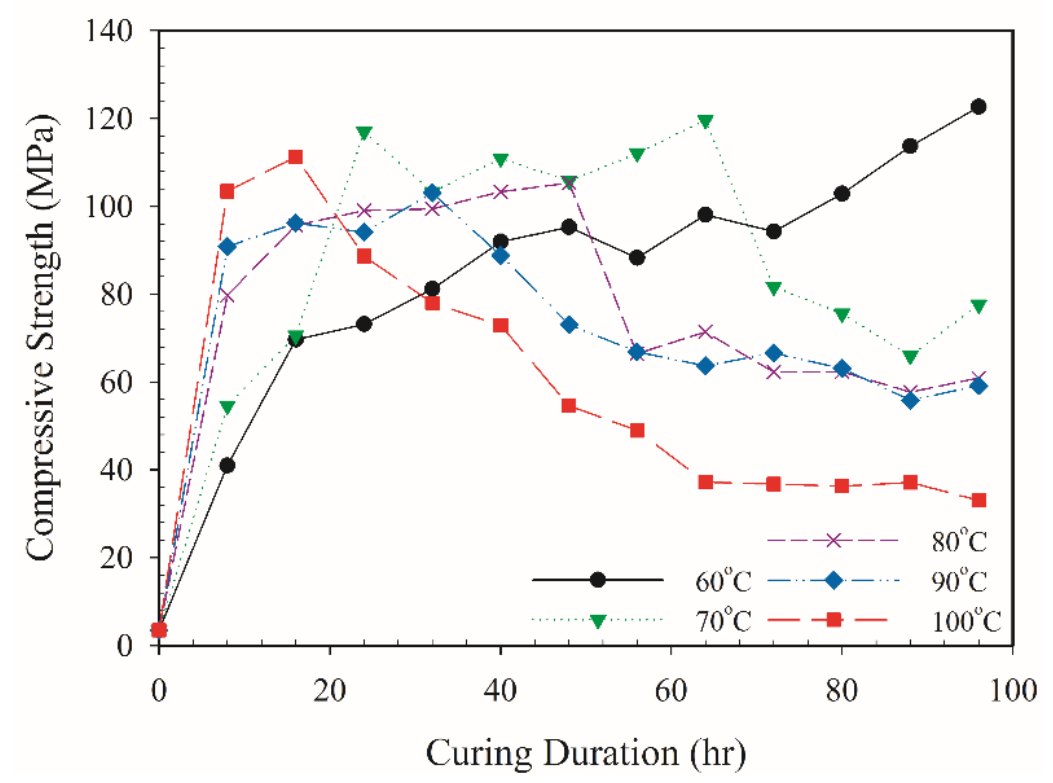

Figure 5. Variations with curing duration in the 4-day compressive strength of geopolymer specimens at various curing temperatures when $\mathrm{AE} \%=4 \%$.

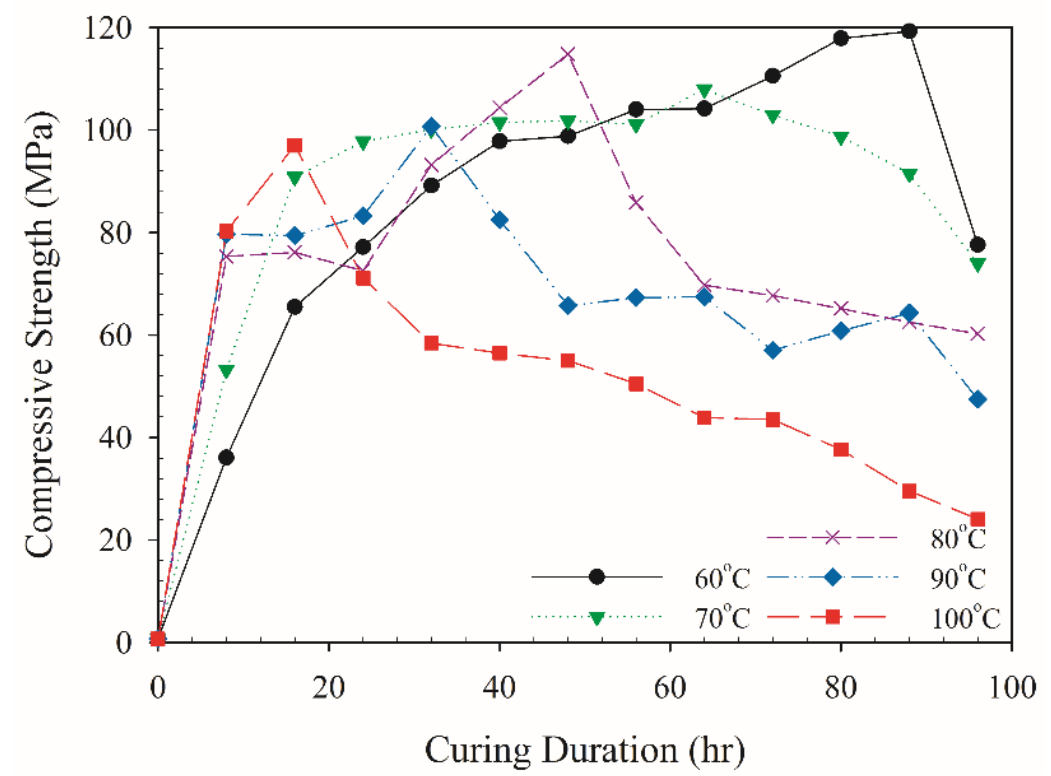

Figure 6. Variations with curing duration in the 4-day compressive strength of geopolymer specimens at various curing temperatures when $\mathrm{AE} \%=5 \%$. 


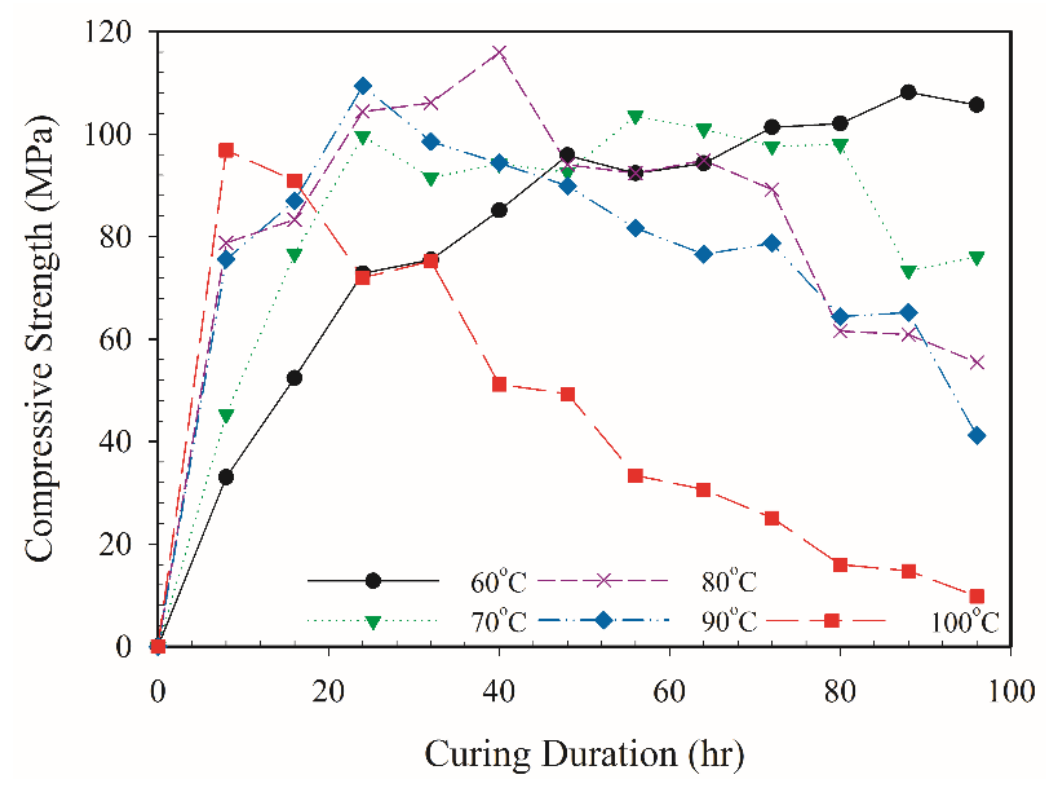

Figure 7. Variations with curing duration in the 4-day compressive strength of geopolymer specimens at various curing temperatures when $\mathrm{AE} \%=6 \%$.

As shown in Figures 2-7, the compressive strength increased with the curing temperature until the optimal curing temperature was reached, regardless of the $\mathrm{AE} \%$. The optimal curing temperature decreased with an increase in the $\mathrm{AE} \%$, indicating that an increase in the curing temperature accelerated the rate at which the glass slurry solidified. However, if the curing temperature continues to rise, the compressive strength then declines. This result is similar to those observed for fly ash and GGBF geopolymers under different curing temperatures [35].

\subsection{Effects of the Curing Duration on the Compressive Strength}

Figures 2-7 present the relationship between the compressive strength and curing duration of the geopolymer specimens at various curing temperatures. The compressive strength increased with the curing duration until the optimal curing duration was reached and then decreased with the curing duration. For a curing temperature of $80{ }^{\circ} \mathrm{C}$ and a curing duration shorter than $24 \mathrm{~h}$, the compressive strength of the specimens with $\mathrm{AE} \%$ of $1 \%, 2 \%$, and $3 \%$ increased significantly with the curing duration, from 2.18 to $50.12 \mathrm{MPa}$, 2.44 to $81.45 \mathrm{MPa}$, and 3.62 to $125.79 \mathrm{MPa}$, respectively. When the curing duration was longer than $24 \mathrm{~h}$, the influence of the curing duration on the compressive strength decreased considerably. Compressive strengths of $69.53,101.89$, and $129.97 \mathrm{MPa}$ were observed at $\mathrm{AE} \%$ of $1 \%, 2 \%$, and $3 \%$, respectively, and at curing durations of 64,48 , and $48 \mathrm{~h}$, respectively. When the curing duration was increased to 4 days, the compressive strengths of the samples with $\mathrm{AE} \%$ of $1 \%, 2 \%$, and $3 \%$ decreased to $59.18,66.78$, and 67.45 MPa, respectively. The specimens with $\mathrm{AE} \%$ of $4-6 \%$ exhibited the same trends as those with $\mathrm{AE} \%$ of $1-3 \%$. For example, at a curing temperature of $70{ }^{\circ} \mathrm{C}$ and curing durations shorter than $24 \mathrm{~h}$, the compressive strength of the specimens with $\mathrm{AE} \%$ of $4 \%$, $5 \%$, and $6 \%$ increased significantly with the curing duration, from $3.47,0.71$, and $0 \mathrm{MPa}$ to $117.01,97.81$, and $99.66 \mathrm{MPa}$, respectively. When the curing duration exceeded $24 \mathrm{~h}$, the influence of the curing duration on the compressive strength decreased substantially. Compressive strengths of 119.65, 107.96, and $103.60 \mathrm{MPa}$ were observed at $\mathrm{AE} \%$ of $4 \%, 5 \%$, and $6 \%$, respectively, and at curing durations of 64,64 , and $56 \mathrm{~h}$, respectively. When the curing duration was increased to 4 days, the compressive strength of the samples with $\mathrm{AE} \%$ of $4 \%, 5 \%$, and $6 \%$ decreased to $77.61,73.98$, and $76.07 \mathrm{MPa}$, respectively.

Except for the specimens cured at $60^{\circ} \mathrm{C}$, all the specimens with $\mathrm{AE} \%$ of $1-5 \%$ exhibited an increase in their compressive strength over 4 days. Regardless of the curing temperature 
or duration, the curing process of the glass-based geopolymer can be di-vided into three phases. During the first phase, the polymerization reaction of the glass is vigorous, and the amount of consolidated colloid increases considerably, strengthening the geopolymer. During the second phase, the compressive strength increases marginally with the curing duration. Low alkali content and curing temperatures necessitate a long curing duration, which results in a clear distinction between the first and second phases. As the $\mathrm{AE} \%$ and curing temperature increase, the second phase becomes less distinguishable from the first phase. Finally, in the third phase, the glass consolidation period extends but the compressive strength decreases. Overcuring led to thermal cracking in the geopolymer, negatively affecting its performance and compressive strength (Figure 8).

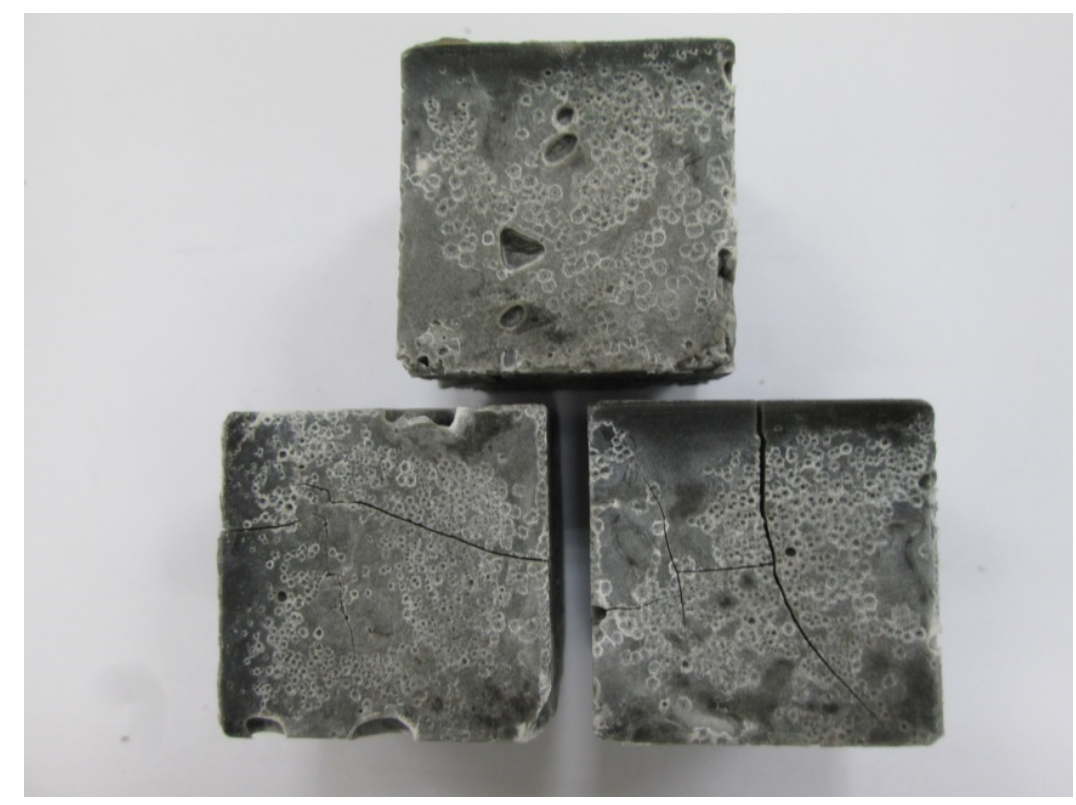

Figure 8. Thermal cracking in geopolymer specimens caused by overcuring.

\subsection{Effects of the Curing Process on Long-Term Strength Development}

As mentioned in Section 3.2, an increase in the curing temperature can shorten the curing duration. Strength development in the specimens was investigated-specifically, that in those with $\mathrm{AE} \%$ of $3 \%$ and $6 \%$ as they were maintained in air for 28 days after constant 24-h curing and curing over 8, 16, 24, 48, and $96 \mathrm{~h}$.

As presented in Figures 9 and 10, among the specimens with an $\mathrm{AE} \%$ of $3 \%$, the specimen cured at $100{ }^{\circ} \mathrm{C}$ over $24 \mathrm{~h}$ had the highest compressive strength $(121.30 \mathrm{MPa})$ after cooling for $1 \mathrm{~h}$ in air. However, after standing in air for 28 days, this specimen had the lowest compressive strength $(51.14 \mathrm{MPa})$ among the specimens with the same $\mathrm{AE} \%$. By contrast, the specimen cured at $70^{\circ} \mathrm{C}$ had a compressive strength of $97.75 \mathrm{MPa}$ after cooling in air for $1 \mathrm{~h}$; however, after standing in air for 28 days, its compressive strength increased to $121.93 \mathrm{MPa}$. Among the specimens with an $\mathrm{AE} \%$ of $6 \%$, the specimen cured at $80^{\circ} \mathrm{C}$ exhibited the highest compressive strength of $83.50 \mathrm{MPa}$ immediately after curing. After standing in air for 28 days, the specimen cured at $60{ }^{\circ} \mathrm{C}$ exhibited the highest compressive strength of $96.08 \mathrm{MPa}$. These results demonstrate that excessively high curing temperatures had adverse effects on the compressive strength of the geopolymer. The researcher speculates that only a part of the geopolymer rapidly solidified within a short period. After standing in air, cracks formed between its regions, reducing its compressive strength. 


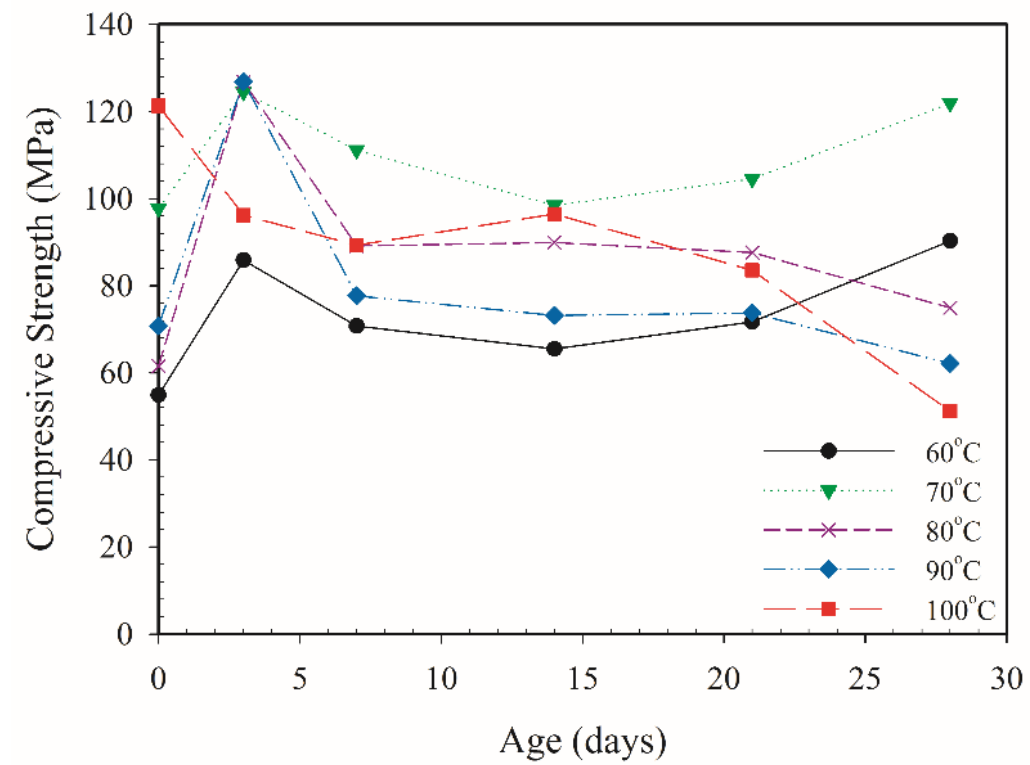

Figure 9. Changes in compressive strength with standing time in air under various curing temperatures after 24-h curing when $\mathrm{AE} \%=3 \%$.

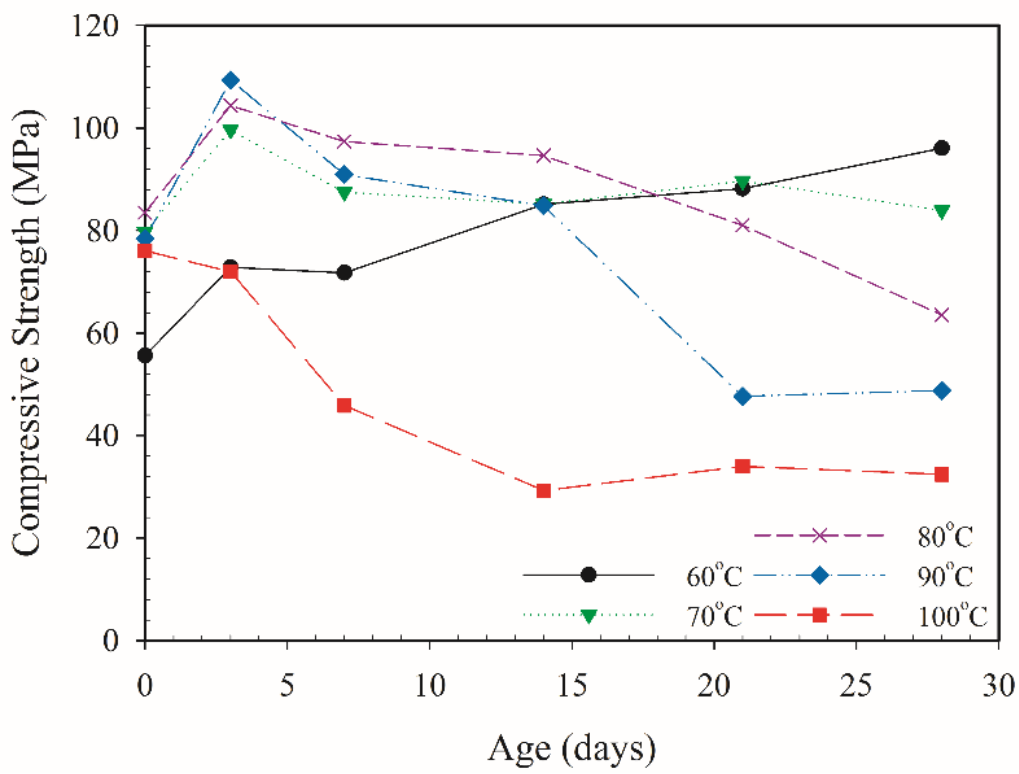

Figure 10. Changes in compressive strength with standing time in air under various curing temperatures after $24-\mathrm{h}$ curing when $\mathrm{AE} \%=6 \%$.

Figures 11 and 12 illustrate the strength development of the specimens that were maintained in air after curing over varying durations. Among the specimens with $\mathrm{AE} \%=3 \%$, the specimen cured for $24 \mathrm{~h}$ exhibited the highest compressive strength of $121.93 \mathrm{MPa}$ after standing in air for 28 days. The specimen cured for $96 \mathrm{~h}$ exhibited the highest compressive strength of $120.75 \mathrm{MPa}$ immediately after curing. Among the specimens with $\mathrm{AE} \%=6 \%$, the specimen cured at $70{ }^{\circ} \mathrm{C}$ for $48 \mathrm{~h}$ exhibited the highest compressive strength of $100.37 \mathrm{MPa}$ immediately after curing. The specimen cured for $24 \mathrm{~h}$ exhibited the highest compressive strength of $83.93 \mathrm{MPa}$ after standing in air for 28 days. These results indicate that the optimal curing duration must be adopted for a glass slurry to dehydrate into a glass-based geopolymer. Excessive thermal energy damages glass microstructures in the long term. The Fourier transform infrared (FTIR) spectroscopy results of the specimens under optimal curing and overcuring conditions are presented in Figure 13. The peak at the 
wavenumber of $1560 \mathrm{~cm}^{-1}$ in the FTIR spectrum of the specimen subjected to overcuring is attributed to the presence of sodium carbonate [36]. No peak was observed in the FTIR spectrum of the geopolymer cured for the optimal duration.

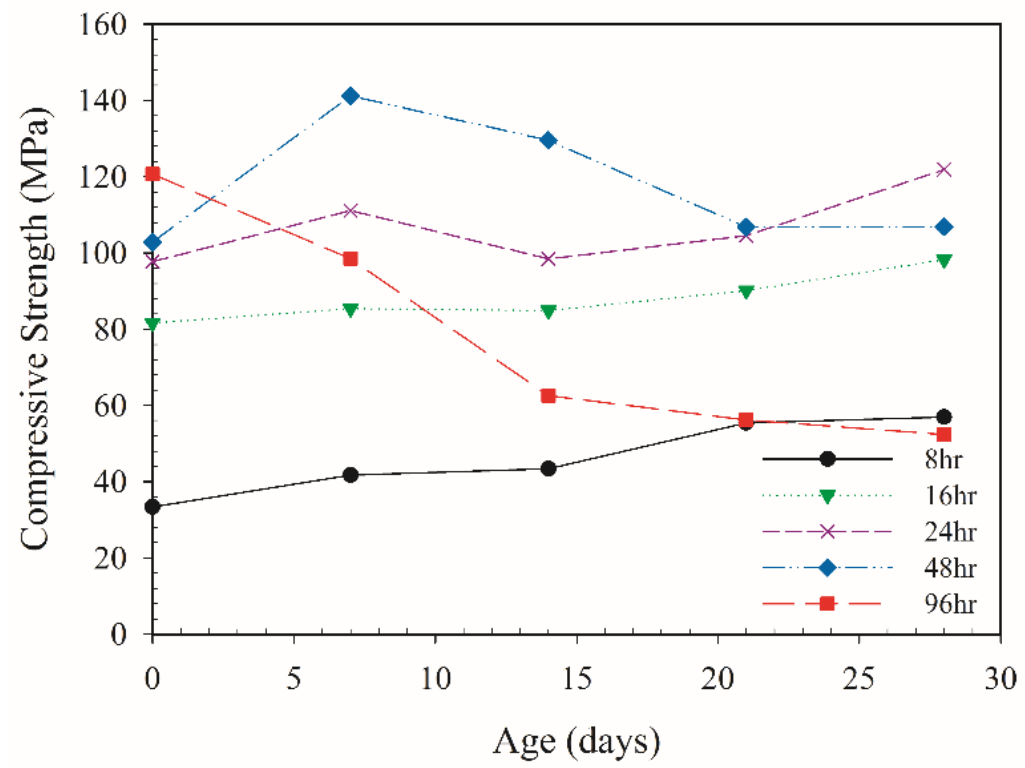

Figure 11. Changes in compressive strength with standing time in air under various curing durations of specimens cured at $70{ }^{\circ} \mathrm{C}$ when $\mathrm{AE} \%=3 \%$.

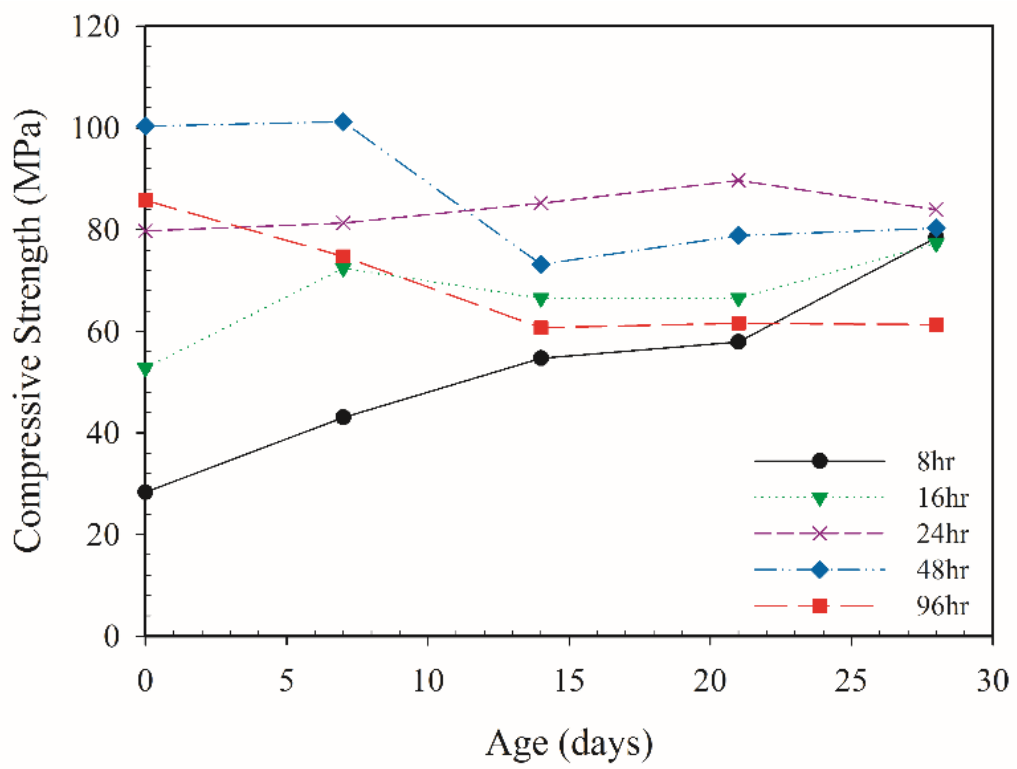

Figure 12. Changes in compressive strength with standing time in air under various curing durations of specimens cured at $70{ }^{\circ} \mathrm{C}$ when $\mathrm{AE} \%=6 \%$. 


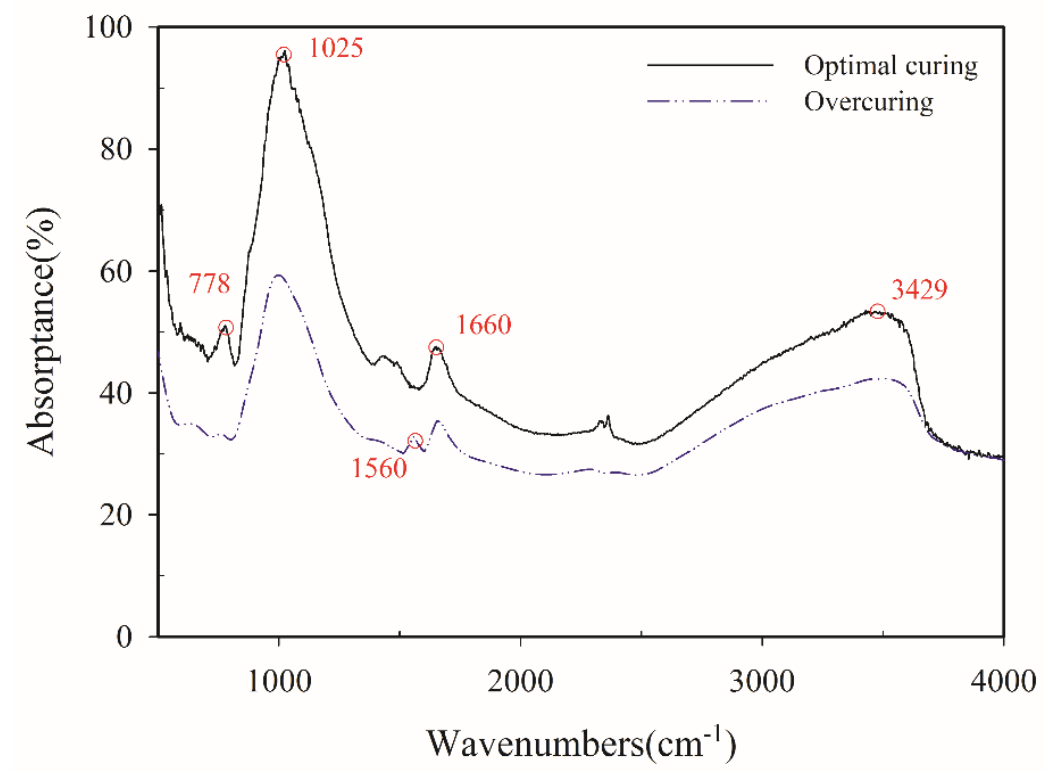

Figure 13. Fourier-transform infrared spectroscopy spectra of a specimen cured for the optimal duration and an overcured specimen.

\section{Conclusions}

The objective of this study was to examine variations in the compressive strength of a glass-based geopolymer subjected to high-temperature curing under the optimal aging process. The results indicate that the compressive strength of the glass-based geopolymer was affected by its solidification process. By increasing the curing duration and temperature the compressive strength specimens were increased. However, overcuring resulted in thermal cracking, reducing the compressive strength. The optimal curing temperature and duction depended on the $\mathrm{AE} \%$. Higher $\mathrm{AE} \%$ required shorter curing durations and lower curing temperatures. Overall, the compressive strength was not influenced by the curing duration and temperature; instead, it was controlled by $\mathrm{AE} \%$.

Excessively high curing temperatures and excessively long curing durations had adverse effects on specimen strength in the long term, with the temperature having particularly severe impact. Therefore, curing temperature should not exceed $70^{\circ} \mathrm{C}$. Furthermore, curing durations shorter than $24 \mathrm{~h}$ enable the gradual development of polymer strength.

Funding: This work received no external funding.

Institutional Review Board Statement: Not applicable.

Informed Consent Statement: Not applicable.

Conflicts of Interest: The author has no conflict of interest to declare.

\section{References}

1. Arndt, N.T.; Fontboté, L.; Hedenquist, J.W.; Kesler, S.E.; Thompson, J.F.; Wood, D.G. Future global mineral resources. Geochem. Perspect. 2017, 6, 1-171. [CrossRef]

2. Hodges, C.A. Mineral resources, environmental issues, and land use. Science 1995, 268, 1305-1312. [CrossRef] [PubMed]

3. Davidovits, J. Geopolymer cements to minimise carbon-dioxide greenhouse-warming. Ceram. Trans. 1993, 37, 165-182.

4. Mehta, P.K. Reducing the environmental impact of concrete. Concr. Int. 2001, 23, 61-66.

5. Xu, H.; Van Deventer, J.S.J. The geopolymerisation of alumino-silicate minerals. Int. J. Miner. Process. 2000, 59, 247-266. [CrossRef]

6. Krizan, D.; Zivanovic, B. Effects of dosage and modulus of water glass on early hydration of alkali-slag cements. Cem. Concr. Res. 2002, 32, 1181-1188. [CrossRef]

7. Davidovits, J. Geopolymers: Man-made rock geosynthesis and the resulting development of very early high strength cement. $J$. Mater. Educ. 1994, 16, 91-139.

8. Davidovits, J. 30 years of successes and failures in geopolymer applications. Market trends and potential breakthroughs. In Proceedings of the Keynote Conference on Geopolymer Conference, Melbourne, VIC, Australia, 28-29 October 2002. 
9. Davidovits, J. Geopolymers: Inorganic polymeric new materials. J. Therm. Anal. 1991, 37, 1633-1656. [CrossRef]

10. Wang, S.D.; Pu, X.C.; Scrivener, K.; Pratt, P.L. Alkali-activated slag cement and concrete: A review of properties and problems. Adv. Cem. Res. 1995, 7, 93-102. [CrossRef]

11. Roy, D.M. Alkali-activated cements opportunities and challenges. Cem. Concr. Res. 1999, 29, 249-254. [CrossRef]

12. Medri, V.; Papa, E.; Lizion, J.; Landi, E. Metakaolin-based geopolymer beads: Production methods and characterization. J. Clean. Prod. 2019, 244, 118844. [CrossRef]

13. Ez-zaki, H.; Bellotto, M.; Valentini, L.; Garbin, E.; Artioli, G. Influence of cellulose nanofibrils on the rheology, microstructure and strength of alkali activated ground granulated blast-furnace slag: A comparison with ordinary Portland cement. Mater. Struct. 2021, 54, 1-18. [CrossRef]

14. Atiş, C.D.; Görür, E.B.; Karahan, O.; Bilim, C.; Ilkentapar, S.; Luga, E. Very high strength (120 MPa) class F fly ash geopolymer mortar activated at different $\mathrm{NaOH}$ amount, Heat Curing Temperature and Heat Curing Duration. Constr. Build. Mater. 2015, 96, 673-678. [CrossRef]

15. Bahrami, M.; Shalbafan, A.; Welling, J. Development of plywood using geopolymer as binder: Effect of silica fume on the plywood and binder characteristics. Eur. J. Wood Prod. 2019, 77, 981-994. [CrossRef]

16. Chindaprasirt, P.; Jaturapitakkul, C.; Chalee, W.; Rattanasak, U. Comparative study on the characteristics of fly ash and bottom ash geopolymers. Waste Manag. 2009, 29, 539-543. [CrossRef]

17. Sun, Q.; Liu, J.; Cheng, H.; Mou, Y.; Liu, J.; Peng, Y.; Chen, M. Fabrication of 3D structures via direct ink writing of kaolin/graphene oxide composite suspensions at ambient temperature. Ceram. Int. 2019, 45, 18972-18979. [CrossRef]

18. Lampris, C.; Lupo, R.; Cheeseman, C.R. Geopolymerisation of silt generated from construction and demolition waste washing plants. Waste Manag. 2009, 29, 368-373. [CrossRef] [PubMed]

19. Shekhawat, P.; Sharma, G.; Singh, R.M. Strength behavior of alkaline activated eggshell powder and flyash geopolymer cured at ambient temperature. Constr. Build. Mater. 2019, 223, 1112-1122. [CrossRef]

20. Yang, K.H.; Lo, C.W.; Huang, J.S. Production and properties of foamed reservoir sludge inorganic polymers. Cem. Concr. Compos. 2013, 38, 50-56. [CrossRef]

21. Dung, N.T.; Chang, T.P.; Chen, C.T.; Yang, T.R. Cementitious properties and microstructure of an innovative slag eco-binder. Mater. Struct. 2016, 49, 2009-2024. [CrossRef]

22. Mehta, A.; Siddique, R. Properties of low-calcium fly ash based geopolymer concrete incorporating OPC as partial replacement of fly ash. Constr. Build. Mater. 2017, 150, 792-807. [CrossRef]

23. Nguyen, H.A.; Chang, T.P.; Shih, J.Y.; Chen, C.T. Influence of low calcium fly ash on compressive strength and hydration product of low energy super sulfated cement paste. Cem. Concr. Compos. 2019, 99, 40-48. [CrossRef]

24. Habert, G.; d'Espinose de Lacaillerie, J.B.; Roussel, N. An environmental evaluation of geopolymer based concrete production: Reviewing current research trends. J. Clean. Prod. 2011, 19, 1229-1238. [CrossRef]

25. Luhar, S.; Cheng, T.W.; Nicolaides, D.; Luhar, I.; Panias, D.; Sakkas, K. Valorisation of glass wastes for the development of geopolymer composites-Durability, thermal and microstructural properties: A review. Constr. Build. Mater. 2019, 222, 673-687. [CrossRef]

26. Adediran, A.; Lemougna, P.N.; Yliniemi, J.; Tanskanen, P.; Kinnunen, P.; Roning, J.; Illikainen, M. Recycling glass wool as a fluxing agent in the production of clay-and waste-based ceramics. J. Clean. Prod. 2021, 289, 125673. [CrossRef]

27. Chen, G.; Lee, H.; Young, K.L.; Yue, P.L.; Wong, A.; Tao, T.; Choi, K.K. Glass recycling in cement production-an innovative approach. Waste Manag. 2002, 22, 747-753. [CrossRef]

28. Suvorova, O.V.; Manakova, N.K.; Makarov, D.V. Use of Bulk Industrial Wastes in the Production of Glass Foam Materials. Glass Ceram. 2021, 77, 384-389. [CrossRef]

29. Ali, S.; Iqbal, S.; Room, S.; Ali, A.; Rehman, Z.U. Value added usage of granular steel slag and milled glass in concrete production. J. Eng. Res. 2021, 9. [CrossRef]

30. Simone, A.; Mazzotta, F.; Eskandarsefat, S.; Sangiorgi, C.; Vignali, V.; Lantieri, C.; Dondi, G. Experimental application of waste glass powder filler in recycled dense-graded asphalt mixtures. Road Mater. Pavement Des. 2019, 20, 592-607. [CrossRef]

31. Christiansen, M.U. Effects of Composition and Activator Type on Glass-Based Geopolymers. ACI Mater. J. 2019, 116, 239-250. [CrossRef]

32. Chen, T.A.; Chen, J.H.; Huang, J.S. Effects of activator and aging process on the compressive strengths of alkali-activated glass inorganic binders. Cem. Concr. Compos. 2017, 76, 1-12. [CrossRef]

33. Chen, T.A. Optimum curing temperature and duration of alkali-activated glass inorganic binders. J. Chin. Inst. Eng. 2020, 43, 592-602. [CrossRef]

34. Hosoi, K.; Kawai, S.; Yanagisawa, K.; Yamasaki, N. Densification process for spherical glass powders with the same particle size by hydrothermal hot pressing. J. Mater. Sci. 1991, 26, 6448-6452. [CrossRef]

35. Verma, M.; Dev, N. Effect of ground granulated blast furnace slag and fly ash ratio and the curing conditions on the mechanical properties of geopolymer concrete. Struct. Concr. 2021. [CrossRef]

36. Swanepoel, J.C.; Strydom, C.A. Utilisation of fly ash in a geopolymer material. Appl. Geochem. 2002, 17, 1143-1148. [CrossRef] 